\title{
War is (not) Our Home. Andrei Konchalovsky's House of Fools (Dom Durakov, 2002) as a Russian Literary and Cultural Archive
}

\author{
BEATA WALIGÓRSKA-OLEJNICZAK
}

\begin{abstract}
The article focuses on the film House of Fools (Dom Durakov, 2002) of Andrei Konchalovsky, who is one of the most recognized contemporary Russian directors. The selected work is analyzed from the point of view of its intertextual relationships with Russian literary texts and cultural phenomena. The motif of the train, the paradigm of jurodivyj and the reference to the artistic worlds of acclaimed Russian writers (Anton Chekhov, Fyodor Dostoyevsky, Leo Tolstoy, Ivan Vyrypaev) are among the main parallels which are discussed in the publication. The eclectic nature of the film allows treating it as a cultural archive founded on the storage capacity of the cultural memory. In the context of war, the sphere of art and the imagined can be seen as the most stable reality.
\end{abstract}

Keywords: Konchalovsky; Dom Durakov; House of Fools; war; Chechnya; Chechen

Andrei Sergeyevich Konchalovsky is one of the best-known Russian directors who has established his position all over the world. He started his career in cinematography in the 1960s, cooperating with Andrei Tarkovsky, which means that his first achievements appeared when a large number of the most acclaimed contemporary Russian film creators had not yet even been born (for example Andrei Zvyagintsev, Kirill Serebrennikov, Alexei Petrovich Popogrebski). In spite of his age (83), he is still an active producer, director and screenwriter, with the premiere of his next film, Dorogiye tovarishchi, planned for 2020. In this context it is worth mentioning his most recognized works such as Uncle Vanya (1970), Siberiade (1979), Maria's Lovers (1984), Runaway Train (1985), Shy People (1987), Tango \& Cash (1989), The Inner Circle (1992), Assia and the Hen with the Golden Eggs (1994), The Postman's White Nights (2014) and Paradise (2016), films which were created either in Russia or in the United States, where he emigrated for several years.

Although House of Fools (Dom Durakov, 2002), which will constitute the sample material for the analysis in this text, does not belong to the most successful films in Konchalovsky's career, it contains his characteristic motifs, 
War is (not) Our Home. Andrei Konchalovsky's House of Fools (Dom Durakov, 2002)

symbolism and inspirations, making it maybe not the canon but definitely his signature work of art on account of its intertextual associations, deeply enrooted in Russian and world culture. The historical theme of the film which can be described as the episodes during the First Chechen War (1994-1996) is not new to the director who often reflects on and expresses his views about the current and past events of Russia's social and political life, for example in the films Siberiade, Maria's Lovers, The Inner Circle, Bitva za Ukrainu (2012), Paradise. In House of Fools Konchalovsky presents (not for the first time either) the microhistory and the microcosm in order to motivate viewers to find in his work the deep study of the history of the world and its universal existential problems and dilemmas. Before pinpointing the cinematic and literary parallels, which is the aim of this paper, one should become familiar with some aspects of the reception of House of Fools in Russia and over the world as well as with basic information associated with its creation.

The plot of the French-Russian coproduction takes place in a centre for mentally ill people situated near the Chechnya-Ingushetia border and is inspired by the real events which happened in 1995 during the Chechen War. Out of the blue the Chechen and then the Russian soldiers enter the grounds of the hospital, which suddenly becomes abandoned by its personnel. The uncomplicated story focuses on the main character, Zhanna Timofeevna, who is played by Julia Vysotsky (privately Konchalovsky's wife), her changing emotional sphere and the relationships between the inmates of the institution. It may seem that the war constitutes merely the background to show some patterns in their behavior and routine. In press, the genre of the film is described in various terms, among which prevail determinants such as: (black) comedy, romance, melodrama, war drama, action, psychological film, or a mix of all these features. The cast includes, apart from Vysotsky, Evgeni Mironov, Sultan Islamov, Stanislas Varkki, Elena Fomina, Marina Politseimako, Rasmi Djabrailov, Vladimir Fedorov and Bryan Adams, in a cameo performance playing himself, i.e. a Canadian pop balladeer singing from time to time his hit song Have You Ever Really Loved a Woman? Despite receiving colossal negative feedback both in Russia and from Western journalists, the film was awarded the Grand Special Jury Prize and UNICEF award at the Venice Film Festival as well as the Jury Award - Honourable Mention at the Bergen International Film Festival. Besides, the work was nominated for the Golden Lion, Golden Eagle and Nika awards.

So far the film has not been widely analyzed. The negative opinions of the critics often focus on Konchalovsky's lack of creativity which is seen in his taking advantage of "the most depleted metaphors from the bottom of the 
cinematic sea: the madhouse as microcosm" and in House of Fools' resemblance to Philippe de Broca's King of Hearts (1966) (Kehr 2003). David Nusair turns attention to the concept of the movie which is interesting contrary to its execution because of the shaky camerawork and the use of various filters disorienting the viewers, pacing issues and the completely pointless and unnecessary presence of Adams (Nusair 2003). A similar view on the latter problem is expressed by Grunes (Grunes 2007). Dan Fainaru, while recognizing the visual imprints of Emir Kusturica and Federico Fellini in Konchalovsky's film, believes that "it is a profoundly Russian piece not only because of the aptly applied allegories, but also because of its melancholy, its pessimism, its choice of fools as the personification of victimized innocence and its mystical longing for dreams that are beyond reach now or at any time in the foreseeable future. The camera travels in long, handheld moves, roaming through the rundown madhouse and catching the inmates at their most vulnerable" (Fainaru 2002). Deborah Young points out that the film "has the comically grotesque appeal of a Fellini film and could reach out to audiences in specialized release". She also turns attention to the image of the Chechen soldiers, who are shown as polite and singing folk songs, which stands in opposition to the pictures dominating in other films touching upon the Chechen wars, e.g. in Aleksei Balabanov's War (Young 2002).

On a positive note Robert Ebert and Joseph Walsh mention the realism, authenticity and a certain unpredictability of the story which derive from engaging actual inmates, who are blended with actors and the film shot in a real mental asylum (Ebert 2003, Walsh 2011). Besides, Ebert emphasizes the fact that knowing and obviously being inspired by One Flew Over the Cuckoo's Nest "Konchalovsky shows courage in pressing ahead into this fraught territory. [...] he salvages a good film from the genre - a film that succeeds not by arguing that the world is crazier than the asylum, but by arriving at the melancholy possibility that both are equally insane" (Ebert 2003). In his opinion "the masterstroke is the use of Bryan Adams, who seems like a joke when he first appears (the movie knows this), but is used by Konchalovsky in such a way that eventually becomes the embodiment of the ability to imagine and dream - an ability, the movie implies, that's the only thing keeping these crazy people sane" (Ebert 2003). Andrew O'Hehir calls Konchalovsky's work "something close to a masterpiece". Although it may be too weird and sentimental, he likes its "peculiarly Slavic combination of grim realism and absurdist fantasy" (O'Hehir 2003). Andrei Plahov categorizes House of Fools as eclectic, puts it in the same stylistic group as The Inner Circle and Assia and the Hen with the Golden Eggs. He also mentions the aspect of theatricalisation noticeable in the film, for example 
in the stylization of Zhanna as the singer Bjork, as well as the importance of the theme of the second-class citizens, which has been monopolized so far by the Russian-Ukrainian director Kira Muratova (Plahov 2018). According to the Russian critic, the film is the manifesto of the authorship cinema, the proof that Konchalovsky definitely gave up the Hollywood stylistics and made an honest and peaceful work about Chechens, showing them simply as human beings. Mikhail Trofimenkov joins those critics who concentrate on the intertextuality of Konchalovsky's work. Apart from associations with Fellini's Masina, Bjork and Chekhov, he underlines the aesthetic analogies with Tom Tykwer's protagonist, Nino Rota's music and Samuel Fuller's films (Trofimenkov 2002).

It can be proposed that Konchalovsky presents the Chechen war as a kind of absurd game whose rules are commonly known and respected but not treated seriously. What really matters is everyday existence with its problems of love, death, and illness, which are similar in every part of the world, independently of the side of the conflict which is supported. Such an approach to life can be seen - among other things - in the chaotic gesticulation of the Chechen soldiers who, out of the blue, start to occupy the premises of the hospital only to disappear after a few days and be replaced by Russians at the end of the film. In the meantime, the time is spent by the soldiers on eating, talking, dancing and occasional shooting. The only stable element in this context is the patients of the institution who stay put whilst their living space is being destroyed and devastated. None of the inmates dies or is imprisoned, which stays in contrast to the soldiers whose strength is diminished. This basic observation could confirm the thesis that Konchalovsky's work is not really a war film but rather a manifesto of humanism and another piece in his career that proves that culture and art constitute the self-sufficient foundation of the earthly existence.

It seems that the core message of House of Fools is fully exposed in the credits of the movie. The division of space into the outside one, which in the course of the film brings about the war, and the inside of the mental centre, which is governed by routine and in a way separated from the world, shows the incompatibility of these realities. The very first image which is introduced after the credit titles is the picture of the rails in a long shot and the landscape of darkness and fog. A rail bridge is shown building up the atmosphere of awaiting and tension. Then, the focus of the camera turns to the group of people standing by the hospital window, their clothes and facial expressions allow the audience to suspect that there is something strange or extraordinary going on. The characters are visibly waiting for something while gazing at the rails, which are located just in front of the hospital building. What is interesting is the fact that first they can be seen as if from the outside, behind the glass separation. 
They resemble children, curious and impatient, with their noses glued to the window. The visual geometry of this image may lead to the associations with the act of looking inside a train carriage while standing on the platform, or the effort to catch a glimpse of the situation which belongs to a different spatial dimension. After this, the camera does get inside to enable the recipient to identify the characters as mentally disabled patients, with their nervous tics, loudly recited monologues, imagined foes etc. Next, the camera comes back outside to show the same group of people again by the window in a different kind of mood, smiling and visibly excited because of the approaching train.

These changes of the camera angles combined with the duality of the location (outside and inside the madhouse) in the very first minutes of the film may be read as the introduction to the strategy used throughout the whole film to emphasize the fact that the war is watched from a distance, as if through the window glass. In a way the war is not real as most of the actual military operations take place behind the scenes, out of the focus of the camera. Besides, the image of the train which is seen approaching, with Bryan Adams as an engine driver, is then - on the following day - replaced by the one of the train pulling tanks and military vehicles. This change not only ruins the patients' everyday ritual but also confirms the fact that the war, similarly to Adams's magical train, does not belong to the inmates' world. Further it could be interpreted that the very beginning of the movie functions as the synecdoche, pars pro toto, presenting in a molecule the problems of the whole film, which is deeply enrooted in the core paradigms and symbolism of the Russian culture.

One of the visual signs which builds up the cultural archive in Konchalovsky's work here is undoubtedly the image of the train itself. This transnational and transcultural motif has been widely present in Russian literary and cinematographic works, in most cases proclaiming the idea of technological progress, the triumph of material civilization or the signal of an upcoming new era of a different way of thinking (e.g. Vasili Pichul's Little Vera, 1988). In some texts, however, the trains were associated with nostalgia for the past or with the noisy life of the city constituting the opposition of the fulfilling existence in the country (e.g. Vera Storozheva's Traveling with Pets, 2007). Here the train, with its blinking head and sidelights, resembles rather a toy or a fancy American truck, a phenomenon which seems strange in the context of both the Russian culture and the military situation shown on the screen. These associations are not misleading, as a series of close-ups of the Canadian balladeer, singing Have you ever really loved a woman? and taking part in a dancing party on the train, prove not only Konchalovsky's use of irony and kitsch but also his surprising exploitation of the metaphor of the selected means of transport. The train, 
War is (not) Our Home. Andrei Konchalovsky's House of Fools (Dom Durakov, 2002)

as suggested by its image, belongs to the world of childish fantasy strictly connected in the film with the state of mind of Zhanna, the most beautiful and naïve patient, who is deeply in love with the legendary singer, her imaginary fiancé. Consequently, the train associates with the oneiric and with unfulfilled dreams, with the journey to the inner, most intimate part of the personality as well as with the illness which makes a human being more sensitive to art and other people. It can be seen in Zhanna's musical talent and good heart, which proves that the mechanical vehicle belongs to the sphere of the spiritual and cultural rather than to the traditional context of civilization and war.

In this context it is worth recalling Robert Rosenstone's reflections concerning the ability of films to show history as live experience. As Ib Bondenbjerg notes referring to Rosenstone's book History on Film - Film on History:

[...] films can recreate the past as a living reality, so that we get a direct sense of how it was "to live then". History classes or reading history books seldom give us this live dimension, this possibility of feeling and experiencing the past. The personification and dramatization of historical realities and conflicts help vitalize historical knowledge and create memory tracks. The way historical films recreate historical events and circumstances is very often highly contested and discussed both by historians and the audience, but the nature of combining historical reality with fiction is precisely to create structures of identification and emotion and insert them into a semi-factual historical reality. A historical fiction film is not a documentary, it is not historical journalism or teaching: it is drama, it is fiction. But historical dramas are important because of the link they can create between structural, large scale history and the history of everyday life. (Bondenbjerg 2012:39)

Although the credit titles of Konchalovsky's work inform the audience that the plot is based on a true episode which happened during the Chechen War, the first minutes of the film, in particular Adams's cameo performance, clearly reveal that it would not be a documentary or fiction recreating real events. There are no dates or military actions which could be recognized, and the visual image of both Chechen and Russian soldiers is stereotyped. It could be said that history is fictionalized and fiction is historicized in the film as it is very hard to tell the difference between these two areas. It seems to be deliberately blurred as it is the fiction, especially the Russian literary and cultural tradition, which functions as the aspect of the reality which is known to the audience, the impulse for emotional and intellectual identification. The strategy of theatralization which is introduced, among other things, in the costumes, gesticulation and make-ups of the inmates could also confirm this thesis. The 
sphere of culture constitutes the stable core which cannot be destroyed by the war. The repetitive appearance of the Canadian balladeer if interpreted as the permanent element of the everyday routine, could prove it too.

As it was noted above, the motif of the train in House of Fools serves as a symbol of the immaterial rather than material reality. It could be further explained as the link between the real and the imagined, the latter sphere in the film being strongly connected to the notion of mental disorder. The patients of the clinic are presented on screen as sensitive and sincere people who under certain conditions - could be potentially aggressive, provocative or even rebellious. These features, building up the personality of the Konchalovsky's carnivalesque characters, could be associated with a number of culturally acquainted motifs such as the carousel, the epitome of oppositions, the symbol combining life and death, joy and sadness, the icon often exploited by directors to show the complexity and ambiguity of film characters. In the context of Russian culture, the most natural connection with the above-mentioned borderline phenomenon would be the paradigm of the foolishness for Christ (so called jurodstvo). It would be hard to find the religious aspect of the foolishness in Konchalovsky's film, but the notion of the mad who can know and see more than the rest of the "normal and healthy" society is definitely emphasized in the discussed film text.

This observation is obviously not new in the context of culture and could lead us to the recognition of literary connotations with understanding the notion of madness in Russia. One of Konchalovsky's favourite and most often exploited traditions is certainly Anton Chekhov's works. His fascination with this writer can be noticed not only in his film adaptation of the drama Uncle Vanya but also in direct verbal and visual allusions to Chekhov's life and texts in his works (e.g. in Paradise) or in building up the Chekhovian characters and atmosphere (e.g. in A Slave of Love, 1976; The Postman's White Nights). A similar case of intertextuality can be found in House of Fools. The application of different filters disorienting the audience, which was contested by David Nusair, can be read as the method of Konchalovsky's subtle association of the lighting used on the set of Uncle Vanya with the meaningful role of shadows and light nuances. The most important inspiration, however, seems to be Chekhov's Ward No. 6 (Palata № 6). The director takes advantage not only of the quite common metaphor of Russia as a madhouse but also constructs the protagonists who are clearly modelled as the continuation of Chekhov's characters. This group could include the character of the good-hearted doctor who is in charge of the institution, understands the patients and knows the new methods of treatment based on the integration of patients at various stages of 
War is (not) Our Home. Andrei Konchalovsky's House of Fools (Dom Durakov, 2002)

their illnesses. The similarity with Chekhov's Ragin can be observed in the doctor's conversations with patients concerning existential problems, the sense of the war, suffering and death. The doctor's calmness and his philosophical approach to life can be seen as the echo of Ragin's mental disputes:

Morality and logic don't come in, it all depends on chance. If anyone is shut up he has to stay, and if anyone is not shut up he can walk about, that's all. There is neither morality nor logic in my being a doctor and your being a mental patient, there is nothing but idle chance. (Chekhov 1892: 23)

While he was reading, and afterwards, while he was going to bed, he kept thinking about Ivan Dmitritch, and when he woke next morning he remembered that he had the day before made the acquaintance of an intelligent and interesting man, and determined to visit him again as soon as possible. (Chekhov 1892: 27)

"We shall never agree, and you will not succeed in converting me to your faith," Ivan Dmitritch was saying irritably; "you are utterly ignorant of reality, and you have never known suffering, but have only like a leech fed beside the sufferings of others, while I have been in continual suffering from the day of my birth till to-day. For that reason, I tell you frankly, I consider myself superior to you and more competent in every respect. It's not for you to teach me."

"I have absolutely no ambition to convert you to my faith," said Andrey Yefimitch gently, and with regret that the other refused to understand him. "And that is not what matters, my friend; what matters is not that you have suffered and I have not. Joy and suffering are passing; let us leave them, never mind them. What matters is that you and I think; we see in each other people who are capable of thinking and reasoning, and that is a common bond between us however different our views. If you knew, my friend, how sick I am of the universal senselessness, ineptitude, stupidity, and with what delight I always talk with you! You are an intelligent man, and I enjoyed your company." (Chekhov 1892: 33)

In the same cohort we could place Ahmed, Zhanna's Chechen military "husband", who rejects the abnormal reality outside and finally decides to join her and the other mentally ill patients in hospital. This gesture, which could be read as motivated by typically Chekhovian melancholy, might be also interpreted in combination with the symbolism of the dancing and singing of the inmates, an activity which appears repetitively throughout the film. Here the sphere of potential associations is much wider, beginning from the carnivalesque dance of the jester temporarily coming into power during the carnival to the meaning of the melancholic waltz of Masha, one of the model characters in Chekhov's 
drama The Seagull, complaining about wasted opportunities (WaligorskaOlejniczak 2009: 72-73).

The multidimensional symbolism of the dance appearing in House of Fools could be also understood in reference to Ivan Vyrypaev's Oxygen (Kislorod, 2009). The ritual of the dynamic, oxygen producing dance constitutes the thematic and the visual core of the above-mentioned drama. It is seen as a special rite which should be practiced by people in order to survive and regenerate the physical and spiritual strength (Biegluk-Leś 2014). The refreshing power of the oxygen in Vyrypaev's play and film is conditioned by repetition and reaching a liberating trance-like situation, which may resemble the behaviour of a mad person or jurodivyj. Analogically, dancing and playing the accordion in Konchalovsky's work brings about the element of change, peace and joy, uniting everyone, particularly at the moment of crisis.

In House of Fools there are some visual elements which function not on a symbolic level but rather as allegories of certain problems characteristic of the artistic world of the canon of Russian writers. One of such motives can be recognized in the image of a white horse nibbling the grass during the conversation of Zhanna and Ahmed after their "engagement". It is the moment of telling the truth as Zhanna confesses to her imagined would-be-husband that she cannot marry him as she has already given her word to Bryan Adams, her fiancé. The statement which - in the beginning - is understood by the soldier as the proof of her naivety in due course leads to Ahmed's expressing his doubts about taking part in the war and killing people. The sign of his vulnerability can be found in his getting drunk quickly as well as in the exposition of his bald head after taking off his military cap, which completely changes his former, macho-like image of a Chechen soldier. The white horse, being the witness of this intimate moment and not quite belonging to the poetics of the dirty and brutal war, on one hand seems to match the incompatibility of these two people with the rest of the world. On the other hand, however, its image definitely brings to mind the associations with the imagery of Fyodor Dostoyevsky and its numerous visual continuations, for example in Andrei Zvyagintsev's Elena. The horse, which is shown on screen, is definitely not an animal prepared for fighting but rather a magical creature, and its fairy tale image could be linked to the metaphor of the white color, which in the European culture often tends to be associated with the new life, wedding and innocence. The dramatic conflict, which is brought about by the bomb suddenly exploding nearby and brutally ending this night of two-party confessions, allows the audience to understand the visual sign of the horse, no longer present on screen, as both the projection of the union of protagonists which cannot be consumed, and their suffering 
because of the unfulfilled dreams and brutality of the war. The allegory derived from the poetics of Dostoevsky's texts could also be a sign of the sacrifice of the innocent, the moment - as it might be noted in Elena - when the egoism and the desire to come into power takes over the rational and the human. Besides, the meaning of this film sequence could be extended by its linking with the direct allusion to the philosophy of Leo Tolstoy and his thoughts on the nature of evil. In Konchalovsky's film the name of the great Russian writer is recalled when the question is asked about the reason for killing people at war. Justification for this kind of behaviour is not to be found in Tolstoy's dogmatic texts. His belief that good should be the only reaction to evil, confirms that the sacrifice epitomized in the image of the white horse can be the only solution to stop spreading evil around the world.

The last but not least aspect worth noting in the discussed film is the issue of ideological content. Konchalovsky's work - as it was mentioned by some critics cited above - could be described as an antiwar text with some allusions to the up-to-date political and social problems. Most of the comments, however, seem to be expressed through the use of irony and the absurd, which in the context of the Russian literary tradition may be associated with the dark humor and poetics of negation of Nicolay Gogol, Anton Chekhov or Venedikt Yerofeyev. The examples of the reference to the very core of this Russian tradition can be found in the scene when Vika finds a tooth in her porridge and interprets the incident as an act of political diversion, in the pictures of the helicopter falling and crashing in front of the hospital, which stays unnoticed and ignored by Zhanna, or in her intention of getting married to the Chechen soldier, which is publicly interpreted by Vika as a protest against the imperial politics of Russia. The chaos which governs the reality infected by the war as well as Konchalovsky's taking advantage of the stylistics of chernukha, the naturalistic inversion of a melodrama - as Seth Graham described it (Graham 2013), can be viewed as another kind of the visual representation of the degradation of the world, to which only art can be a stable alternative.

The presented case study of Konchalovsky's House of Fools reveals that the intertextuality and eclecticism of his work can be observed on many levels. The visual references to Fellini and Kusturica, most often pinpointed by the critics, confirm that the work may be viewed as a very capacious cultural archive, the foundation of which has been built by Konchalovsky's deep knowledge of the Russian literary and cultural paradigms. The associations with the strategies of carnivalisation, the cultural motif of the train and the carousal, the meaning of the dancing, as well as the direct allusions to the works of Chekhov, Dostoyevsky, Tolstoy or Yerofeyev - among others - should be 
treated as the impulses and motivation for future research. This brief sketch shows the potential of possible explorations and at the same time the proof of Konchalovsky's belief that the sphere of the imagined and intellectual is far more stable than the material and civilizational as it constitutes the spiritual reservoir which is preserved and added on by the flow of generations. In conclusion, it can be said that Konchalovsky's approach could be further explored in the context of Aleida Assmann's notions of the cultural and storing memory, which were proposed by the German scholar as useful tools to study the phenomenon of the collective memory.

\author{
Beata Waligorska-Olejniczak \\ beata.waligorska@amu.edu.pl \\ Adam Mickiewicz University in Poznan \\ Faculty of Modern Languages and Literatures \\ Institute of Russian and Ukrainian Philology \\ Department of Comparative Studies in Literature and Culture \\ al. Niepodległości 4 \\ 61-874 Poznań \\ POLSKA / POLAND
}

\title{
Bibliography
}

Biegluk-Leś, W. 2014. Nieradosne gry kulturowej dekonstrukcji. Tlen Iwana Wyrypajewa. - Białostockie Studia Literaturoznawcze, 5, 371-392, http://bsl.uwb.edu. pl/download/bsl5/24-Biegluk-Les.pdf (28.01.2020).

Bondebjerg, I. 2012. Confronting the Past. Trauma, History and Memory in Wajda's Film. - Images, XI (20), 37-51, https://pressto.amu.edu.pl/index.php/i/article/ view/3486

Chekhov, A. 1892. Ward No. 6. - http://www.eastoftheweb.com/short-stories/ UBooks/WardNumb.shtml (28.01.2020).

Ebert, R. 2003. https://www.rogerebert.com/reviews/house-of-fools-2003 (28.01. 2020).

Fainaru, D. 2002. House of Fools (Dom Durakov). - https://www.screendaily.com/ house-of-fools-dom-durakov/4011255.article (28.01.2020).

Graham, S. 2013. Tales of grim: Seth Graham on the dark side of Russian cinema. https://www.calvertjournal.com/articles/show/57/chernukha-little-veracargo-200 (28.01.2020).

Grunes, D. 2007. House of Fools (Andrei Konchalovsky, 2002). - https://grunes. wordpress.com/2007/04/08/house-of-fools-andrei-konchalovsky-2002/ (28.01.2020). 
War is (not) Our Home. Andrei Konchalovsky's House of Fools (Dom Durakov, 2002)

Kehr, D. 2003. FILM IN REVIEW; 'House of Fools'. - https://www.nytimes. com/2003/04/25/movies/film-in-review-house-of-fools.html (28.01.2020).

Nusair, D. 2003. House of Fools. Andrei Konchalovsky. - http://exclaim.ca/film/ article/house of fools-andrei konchalovsky (28.01.2020).

O’Hehir, A. 2003. "House of Fools". - https://www.salon.com/2003/05/02/house of_fools/ (28.01.2020).

Plahov, A. 2018. Dlinnaâ distanciâ: Andrej Končalovskij. - https://seance.ru/ articles/dlinnaya-distanciya-andrej-konchalovskij/ (28.01.2020).

Trofimenkov, M. 2002. “Dom durakov” otkryvaet dveri. Fil'm Andreâ Končalovskogo vyšel v rossijskij prokat. - https://www.kommersant.ru/doc/346545 (28.01.2020).

Waligorska-Olejniczak, B. 2009. Sceniczny gest w sztuce A.P. Czechowa "Mewa" i taniec wyzwolony jako estetyczny kontekst Wielkiej Reformy Teatralnej. Poznań: ESUS.

Walsh, J. 2011. Barbican Film: Andrei Konchalovsky's 'House of Fools'. - https:// cine-vue.com/2011/01/barbican-film-andrei-konchalovskys-house-of-fools.html (28.01.2020).

Young, D. 2002. House of Fools. - https://variety.com/2002/film/reviews/house-offools-2-1200546390/ (28.01.2020). 